Andżelika Dzięgiel ${ }^{1}$

The Department of Enterprise Management

Faculty of Economic Sciences and Management

Nicolaus Copernicus University in Toruń

\title{
Satisfaction survey of basketball fans at the example of the club Twarde Pierniki
}

\begin{abstract}
Increasing the quality of service is one of a main objective of service companies, including sporting organizations. A significant increase of leisure activities has influence on strong competition among the organizers of the cultural, social and sport events. The regular surveys of satisfaction are one of the elements of relationship marketing, which are necessary to get the high attendance of fans on events, e.g. basketball matches. In the article as an object of study has been chosen the club Twarde Pierniki. The main objective of the research was the assessment satisfaction from sports products offered by the basketball club and improvement their quality based on responses received from the customers - basketball fans. In 2015 by means of on-line survey method was conducted research in which participated 235 respondents. The results showed that the evaluations of organization of sports event (basketball matches, additional attractions), marketing and social activities of the club, as well merchandise in The Fan Shop, are high. Only The Fan Club was rated lower than other components of the club activities.
\end{abstract}

Keywords: satisfaction survey, relationship marketing, basketball fans, Tauron Basket League, Twarde Pierniki, Torun

\section{Introduction}

Sports is without any doubt a serious business nowadays. Professional sporting organizations generate huge incomes every years e.g. National Football League had revenue above 12 billion dollars in $2015^{2}$. Shank (2008) sports product defines as "a good, a service, or any combination of the two that is designed to provide benefits to a sports spectator, participant, or sponsor". What is important, in the case of sports products of basketball club in much greater extent involve services rather than goods. Furthermore, the consumption takes place mainly during the event and it is difficult to improve it, as in the case of a normal material product (Klisiński 2008).

\footnotetext{
${ }^{1}$ mgr Andżelika Dzięgiel, e-mail: dzięgiel@doktorant.umk.pl

${ }^{2}$ http://money.cnn.com/2015/09/10/news/companies/nfl-revenue-profits/ (accessed 26 May 2016).
} 
Sporting organizations often have to operate in competition - in national dimension (e.g. clubs in the same discipline such as NBA) and international dimensions (such as the UEFA Champions League in football). The crux of the biggest problems are related to the increasing competition between organizers of events and a low level of knowledge about the needs of participants in events. Hence important is cooperation with various stakeholder groups. In the case of basketball club stakeholders include passive participants of the events (fans), sponsors, media, government, local community, external companies, employees, volunteers and competitors.

According to Perechuda (2006) researches of customer needs and expectations are associated with the process of communicating with the market and their results should provide guidance for marketing activities. This article was devoted to the study of satisfaction the most numerous groups of stakeholders fans. What is more, the whole sports business depend on fans. Building of events in line with expectations of its customers, especially the fans who create the atmosphere of match, is necessary to obtain the satisfaction of the other stakeholder groups (Waśkowski 2007). When the sports event attracts more fans, it surely sponsors and governors of cities and local tourism economy or outsourcing companies, will be also satisfied. Summing up, the whole sports business depends on fans.

\section{Relationship marketing in sport}

Marketing literature has barely fifty years old. Nevertheless, during those fifty years the way of thinking about marketing and way how is practiced has changed significantly (Chistopher et al. 2013). Marketing is a broad and variously defined concept, which in its area covers the principles of the market, which should be used by the company, including also by sporting organizations. In recent years, when the changes took place in modern business also evolved the approach to marketing. As a result, increasing the degree of saturation of markets and knowledge about consumers and competition, enterprises focus on relationship and individualization of customers, rather than a transactional marketing (Armstrong and Kotler 2012). Relationship marketing began to be one of the most important factors of building long-term success of the company by matching the offer to the customers' expectations. Therefore the sporting organizations, which are treated as mediumsized enterprises (due to the number of employees and annual turnover), are obliged to adapt to the rules prevailing in the market including trends in marketing (Sznajder 2012).

Genesis of relationship marketing dates back to the 60th century, when the results of analyzes of scientists from the University of Upssala pointed to the importance of long-term benefits in the marketing activities of companies in the business-to-business market (abrev. B2B). The creator of the first definition of relationship marketing was Leonard Berry, who in 1983 described the concept as the creation, maintenance and enrichment of the customer relationship (Otto 2004). Essential to this process is the consistent use of updated knowledge about individual 
needs and expectations of customers both for the creation of relevant products or services, but also to develop and continue the mutual benefits (Christopher et al. 2013). Research, which were conducted so far, show that maintaining stable relationships with customers are cheaper than attraction of new customers, as well as, leads to improve the company's position in the market e.g. through an increase in the number of recommendations (Rudawska 2011).

To this day, the theoretical base assumptions of the concept of relationship marketing form the three aspects of building relationships suggested by Berry. The first is the creation of relationships. In the case of basketball games, relationship between professional sporting organizations with their fans starting from guarantee them watching game live, providing professional announcer, sanitary facilities and catering, as well as, access to free parking spaces and the high level of general services (e.g. professional protection, several information points). In the case of sponsors and media relationship are created on the stage of individual conversations, in the course of which is presented proposals for cooperation opportunities.

The second step of individual marketing is maintaining relations between sporting organizations and their stakeholders by mutual dialogue. Communication can take place through various instruments like Internet (especially in social media, by newsletter) and mobile-marketing. It should be mentioned about the special loyalty programs. The main task for loyalty program is to reward solid and engaged customers by offering an attractive and personalized proposals for further cooperation e.g. fan card offers lower tickets price, extraordinary services on the matches and discounts for merchandise, as well as, cheaper drinks in local pubs (Petrykowska 2014).

The third stage of relationship marketing is the development and continuous improvement of basic offer, which influence on the overall quality of the products or services. It includes enrichment basic offer by additional services (extraordinary). The knowledge of the needs and perceptions of additional services, can turn out a key direction to achieve competitive advantage on the sports events market.

To maintain relationships with fans by sporting organizations are necessary the regular satisfaction surveys from participation in a sports event, as well as, should be implement the changes suggested by the respondents. According to Bühler and Nufer (2012) sporting organizations need to know who their customers are and where they can find them. Customer research is therefore an inevitable prerequisite for relationship marketing. The survey of satisfaction with participation in sports event serves to minimize the difference between the supplied sports product by the organizers and the expectations of the customer to this product (Golas and Mazur 2011). This article is mainly focused on satisfaction survey, which is element of relationship marketing.

\section{Objective and method of study}

The main objective of the research was the assessment satisfaction from sports products offered by the basketball club and improvement their quality based on 
responses received from the customers - basketball fans. Identify and describe the expectations and needs of the key stakeholders of the analyzed sports event (i.e. basketball fans) is necessary to improve the sports product (e.g. a basketball game, merchandise). Analysis of the opinions and the proposed changes suggested by basketball fans (stakeholders) are an important component of the research verifying satisfaction from taking part in sports event in the passive way. In this article as a subject for analysis were selected club Twarde Pierniki, which in 2014 began playing basketball in the highest level in the hierarchy of the class of men's basketball league in Poland (i.e. Tauron Basket League, abrev. TBL). Twarde Pierniki is a basketball club which was established in 2004 in Torun with initiative basketball enthusiasts. From 2015, when basketball team from Torun began playing in the TBL, has name from two the biggest sponsors of club and is called Polski Cukier Torun's.

After the end of the season in 2015, using the method CAWI was carried out a survey among basketball fans of team Polski Cukier Torun. Invitation to participate in the survey were sent e-mails for registered users of newsletter and made available on the official website of the club, as well as, on a dedicated Facebook profile.

The choice of the samples for the research was targeted. The respondents were belonged to basketball fans of team from Torun. In this research was gained a satisfactory sample size - 235 respondents. In this research used to measuring instrument, which was consisted mostly of closed questions. However, there was possibility to introduce additional indications and comments by using option "other". In order to obtain a more complete opinions and suggestions from the basketball fans in the questionnaire also included open-ended questions. In aspects related to the evaluation of satisfaction there were used of 6-point the numerical scale, which is example of The Likert Scale (Kaczmarczyk 2011), on which the respondents had to indicate the extent to which these elements reflect their level of satisfaction, where "1" meant very low, and "6" very high.

The questionnaire consisted of six parts. It began by examining the overall experience of supporting different sports teams. Another parts involved the evaluations of sport events (matches and additional attractions), marketing and social activities of club, as well The Fan Shop and The Fan Club. At the end of the questionnaire were questions about the profile of the respondent. In this article were presented only responses from selected questions.

A holistic approach to the subject also required a desk research. For this study were used several sources of information available in paper version or in electronic form. In turn, the most recent data were obtained from Internet resources. In addition, some of the information involved author's experiences and observation.

\footnotetext{
${ }^{3}$ http://twardepierniki.pl/klub/historia (accessed 26 May 2016).
} 


\section{Results and discussion}

In this study involved 235 people. In the profile of the respondent examined how the socio-demographic characteristics have people who are the fans of basketball games. The analysis included gender, age, education, marital status, work position and evaluation of the financial situation. The analysis of gender structure shows that the vast majority of basketball fans are men $-86 \%$ of the respondents and the remaining $14 \%$ of the sample are women.

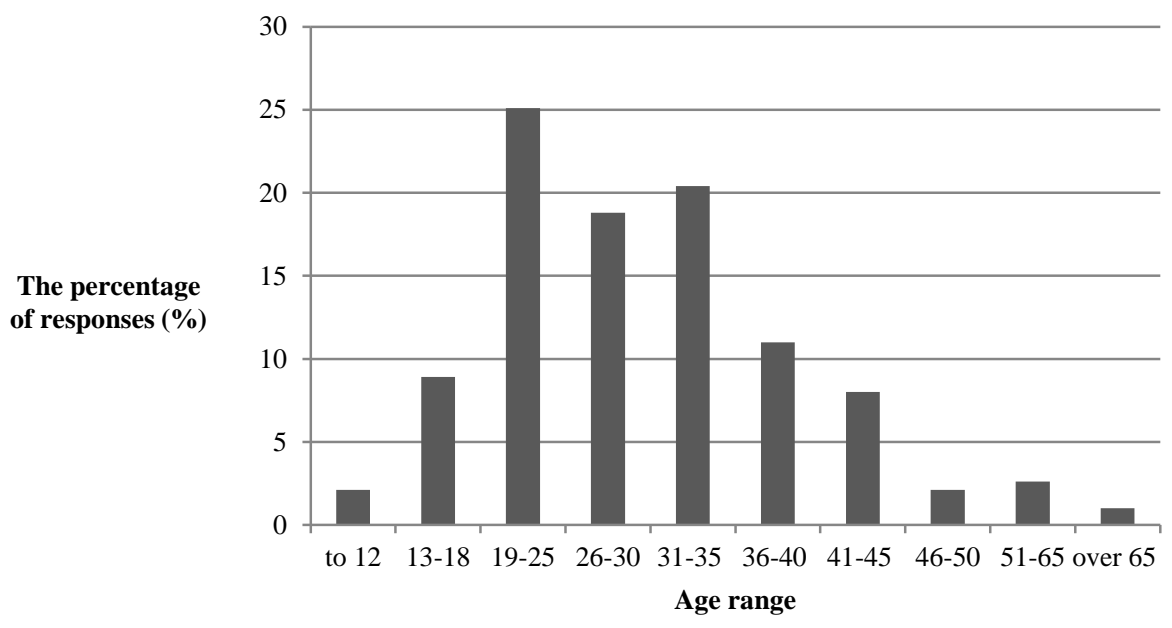

Fig. 1. The age structure of the respondents.

Source: own study based on survey.

Most of the surveyed fans are young people who have not yet crossed the thirtysixth year of life, including the largest group was aged 19-25. Detailed age structure shows Figure 1. At the time of the study, most of the respondents (54\%) declared that have higher education or postgraduate studies and $11 \%$ were students. With the fact of the young age of the respondents until 55\% were not being married. Further results show that the most respondents (34\%) indicated that they work as specialist or independent worker. The second largest group (25\% of respondents) are young people (students) who are in the course of further education.

The percentage of other work position of basketball fans shows Figure 2 . 


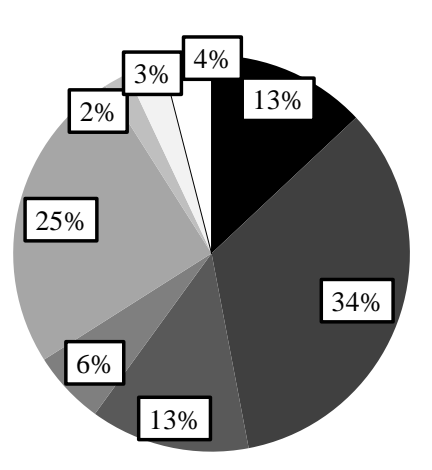

\author{
- blue-collar worker \\ - specialist or independent worker \\ - mid-level manager (manager) \\ - management team (director / president) \\ student \\ retiree \\ unemployed \\ $\square$ other
}

Fig. 2. The work position of the respondents.

Source: own study based on survey.

The last point but not the least, in the profile of the respondent examined the financial situation of the basketball fans. The most of the respondents $(51 \%)$ said that "I must be careful on my spending, but I can afford to put aside a certain amount per month". Until 35\% examined of basketball fans said that they not have to limit their daily spending, because they have enough money for most needs.

In the next part of the questionnaire checked experiences from being fan in sports. In first question were studied how long respondents are basketball fans. The most respondents $(51 \%)$ began to watching basketball games when they had from 11 to 16 years. Almost every fourth among surveyed people (23\%) indicated the age of 17-24 years. This means that sport lovers become basketball fans in youth.

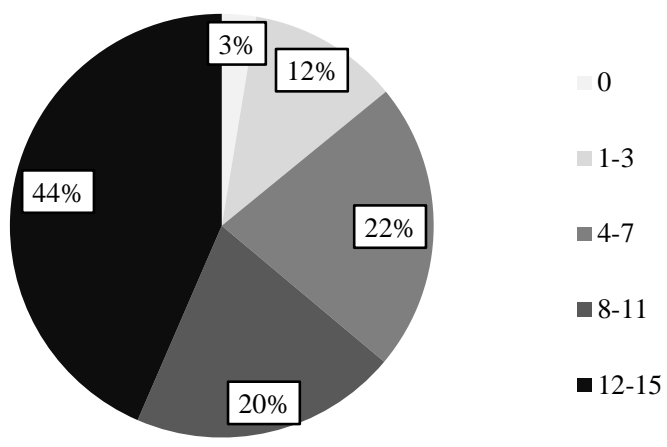

Fig 3. The frequency of participation in the matches in home of the team Polski Cukier Torun in the season 2014/2015.

Source: own study based on survey. 
In next question was examined the frequency of participation in the matches of the team Polski Cukier Torun in the season 2014/2015 (Figure 3). The results show that in this study participated mainly experienced basketball fans - until $64 \%$ of respondents attended at least 8 of the 15 matches, which took place in Torun.

In the next part of the questionnaire was examined why it is worth being basketball fans (Figure 4). In this question was a possibility of multiple choice. The vast majority of respondents considered the entertainment as the main benefit of being the basketball fans. The vast majority of respondents $(72 \%)$ considered matches as a good entertainment and the main benefit with being the basketball fans. Additionally, for $67 \%$ of respondents variety of emotions on the matches are very important. More than half of the people surveyed believed that pride from every victories of favorite basketball team form some kind of advantages e.g. positive emotion and attitude to life. Quite a few respondents were indicated also on the opportunities to admire the skills of players (45\%) and spend time with friends $(40 \%)$ on the basketball games. Other responses were selected by less than every third person.

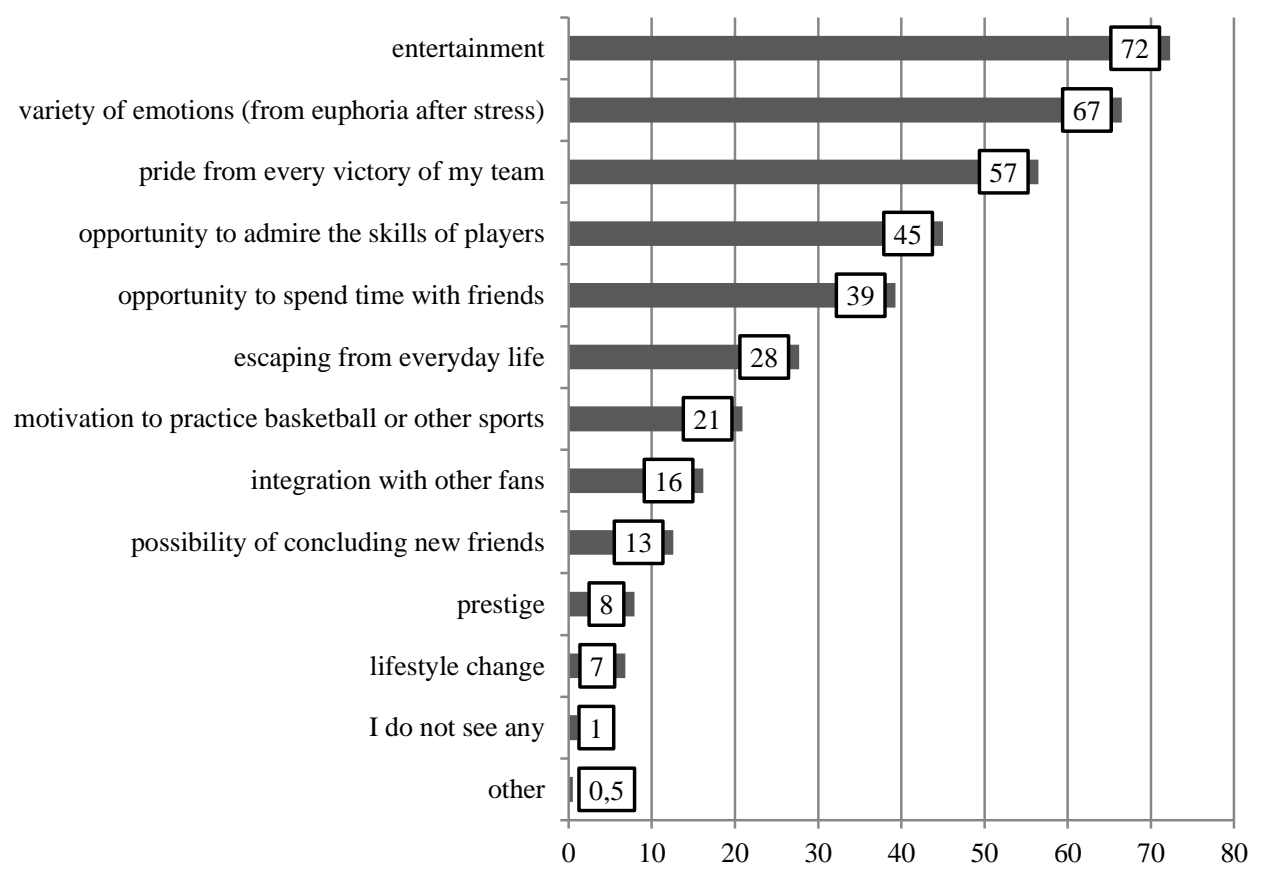

The percentage of responses $(\%)$

Fig 4. The most important benefits of being a basketball fans according to respondents. In this question was a possibility of multiple choice.

Source: own study based on survey. 
In subsequent parts of the questionnaire were included questions covering the respondents' evaluations of sports event (matches and additional attractions), marketing and social activities, The Fan Shop and The Fan Club. In first step respondents were questioned about evaluation of the level of organization of matches of team Polski Cukier Torun in home in the season 2014/2015. The respondents were asked to select a score from 1 to 6 , where " 1 " meant a very negative evaluation and " 6 " meant very positive evaluation. In this study, the largest number of respondents (46\%) gave score of 5. Subsequently, most of the respondents evaluated their level of satisfaction on the good level - scores 4 selected $28 \%$ of respondents. The assessment of 3 and below gave only $6 \%$ of examined fans. In turn, the average rating of all responses was 4.77.

In order to analysis of the individual components of the quality of the organization of sports event and study the level of satisfaction with them, respondents were asked to evaluate of attractions before and during the basketball games. Average scores, which were given by respondents, are presented in Table 1. In this study were analyzed 15 attractions of match. The vast majority attractions $(60 \%, 9$ out of 15$)$ received a score of higher than 4 . The highest average rating obtained presentation of players -4.96 . The next a high score respondents gave for post-match meeting with fans (4.71) and then special showing of club mascot (4.64). In turn, the lowest scores achieved: gastronomy (3.45), the presence additional of entertainers (3.59) and attractions provided in the lobby (3.80). It is worth noting that, the club Twarde Pierniki unfortunately has not influence on gastronomy during own matches. Because Board of Directors of sports hall, where take place the basketball games, are responsible for catering outlets in the hall. Furthermore, the low score of additional entertainers (the fairy-tale characters) is likely caused too small engagement of clowns in emotion and activity during sports event. The respondents gave also low grades for attractions provided in the lobby hall. It may be caused the insufficient promotion that extraordinary attractions, as well as, fact that the first attempt to engage fans to additional activities before and during matches was unsuccessful. Nevertheless, the club Twarde Pierniki should improve those form of entertainment.

Tab. 1. Level of satisfaction with additional attractions before and during the matches

\begin{tabular}{|l|c|}
\hline Attractions before and during the matches & Average rating \\
\hline atmosphere & 4.22 \\
\hline presentation of players & 4.96 \\
\hline performances of dance group Cheerleaders Torun & 3.81 \\
\hline kids zone (children's play area) & 4.51 \\
\hline showing of club mascot (Rycerz Piernisław) & 4.64 \\
\hline presence of entertainers (clown) & 3.59 \\
\hline announcer & 4.07 \\
\hline musical & 4.42 \\
\hline competitions carried out before and during the breaks between quarts & 4.49 \\
\hline competitions carried out in the lobby & 3.86 \\
\hline
\end{tabular}




\begin{tabular}{|l|l|} 
attractions provided in the lobby & 3.80 \\
\hline gastronomy & 3.45 \\
\hline The Fan Shop & 4.17 \\
\hline The Fan Club & 3.83 \\
\hline post-match meeting with fans & 4.71 \\
\hline
\end{tabular}

Source: own study based on survey.

In the next part of the questionnaire checked, which attractions are the most interesting for respondents and should be present during basketball games in Torun in the next season (Figure 5). Almost half of the respondents (47\%) considered that competitions with valuable prizes and exhibition of basketball history are the most interesting attractions and should be available in every matches. Almost every third respondent pointed at the EXPO (sports equipment and local products) and tasting local delicacies, like an additional value during basketball matches. Other responses pointed less than $30 \%$ of examined fans.

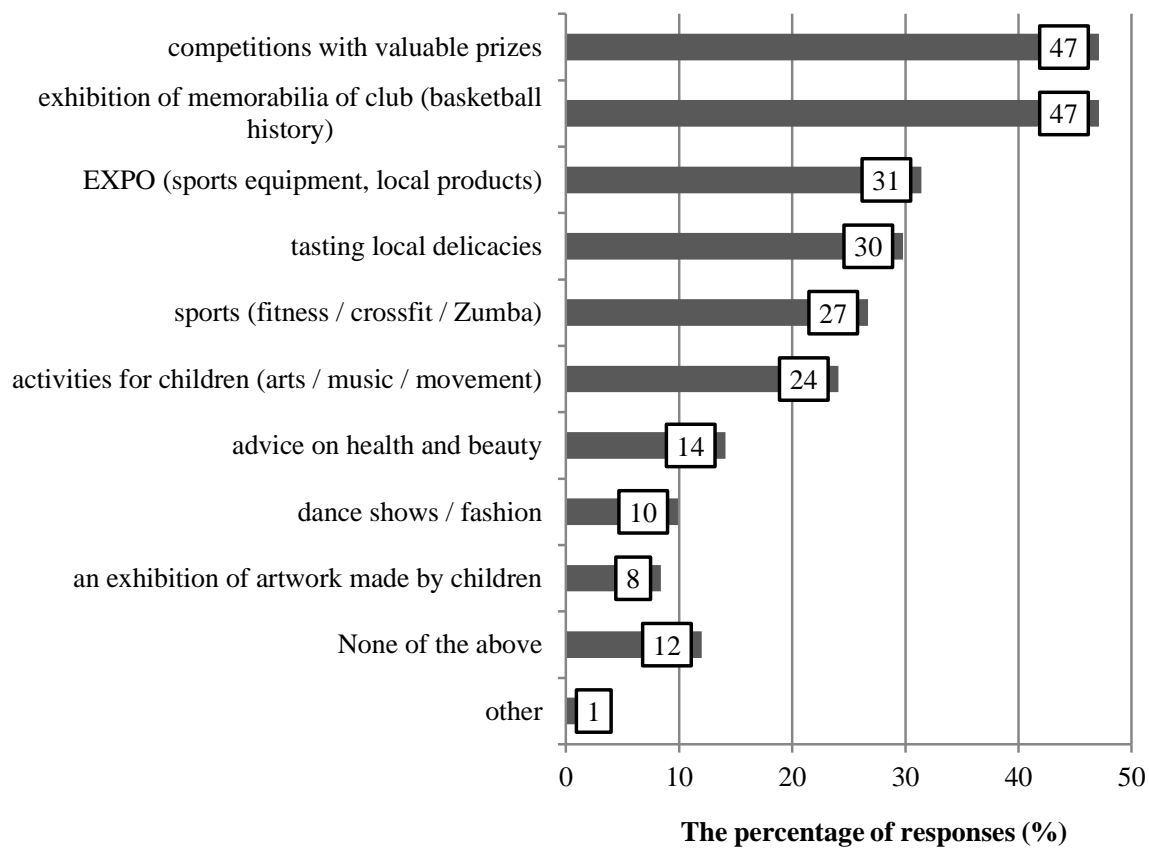

Fig 5. The most interesting attractions which should be present during basketball games in Torun in the next season, according to the respondents. In this question was a possibility of multiple choice.

Source: own study based on survey. 
Another part of the study was focused on marketing and social activities of club Twarde Pierniki. Among marketing actions realized by analyzed club the respondents gave the highest assessment on visiting basketball players and mascot club in kindergartens (average rating was 5.07). A high score (4.91) received also organization the trips for fans on the away matches. Additional, current contact with fans in social media (Facebook, Twitter, Instagram) was high valued (4.80). The respondents pointed the lowest rating for series club "Między Nami Twardymi Piernikami". It should be noted that the low score is related to with too small number of episodes and lack of continuing series on the whole season. It is worth noting that none of these marketing or social activities received a lower average rating than 4.17. It can be considered that the fans are satisfied with the club activities in the marketing and in the social dimension.

Tab. 2. Level of satisfaction with elements of marketing and social activities of club Twarde Piernki

\begin{tabular}{|l|c|}
\hline Elements of marketing and social activities of club & Average rating \\
\hline graphic design materials & 4.52 \\
\hline films promoting the upcoming matches & 4.69 \\
\hline shortcut films with matches & 4.69 \\
\hline series club "Między nami Twardymi Piernikami" & 4.17 \\
\hline patron of the event "Red Bull King of the Rock" & 4.20 \\
\hline current contact with fans in social media & 4.80 \\
\hline thematic matches (on the occasion of Women's Day, Christmas and Easter) & 4.79 \\
\hline organization of together tours for fans on the away matches & 4.91 \\
\hline competitions in social media for football fans & 4.53 \\
\hline ticket competitions with Radio GRA & 4.65 \\
\hline visiting basketball players and Rycerza Piernisława in kindergartens & 5.07 \\
\hline
\end{tabular}

Source: own study based on survey.

In another aspect of this study was checked the degree of satisfaction respondents with The Fan Shop. The most of the respondents evaluated their level of satisfaction from The Fan Shop on the good level - scores 4 selected 34\% of respondents. The assessment at least 5 gave $27 \%$ of examined fans. In turn, the average rating of all responses was 4.09. In the next part of the questionnaire was examined what gadgets of club (merchandise) respondents would like to buy in the next season. Most respondents pointed to T-shirt with the logo of club (55\%) and the replica of shirt of favorite team (53\%). More than $20 \%$ of respondents also indicated on a baseball cap, a cup, a mascot for children. From 10 to $20 \%$ of respondents pointed on a winter caps, a lanyard, a mini shirt, a towel, a scarf, a wristband, a magnet, a sticker with the logo of the club. 


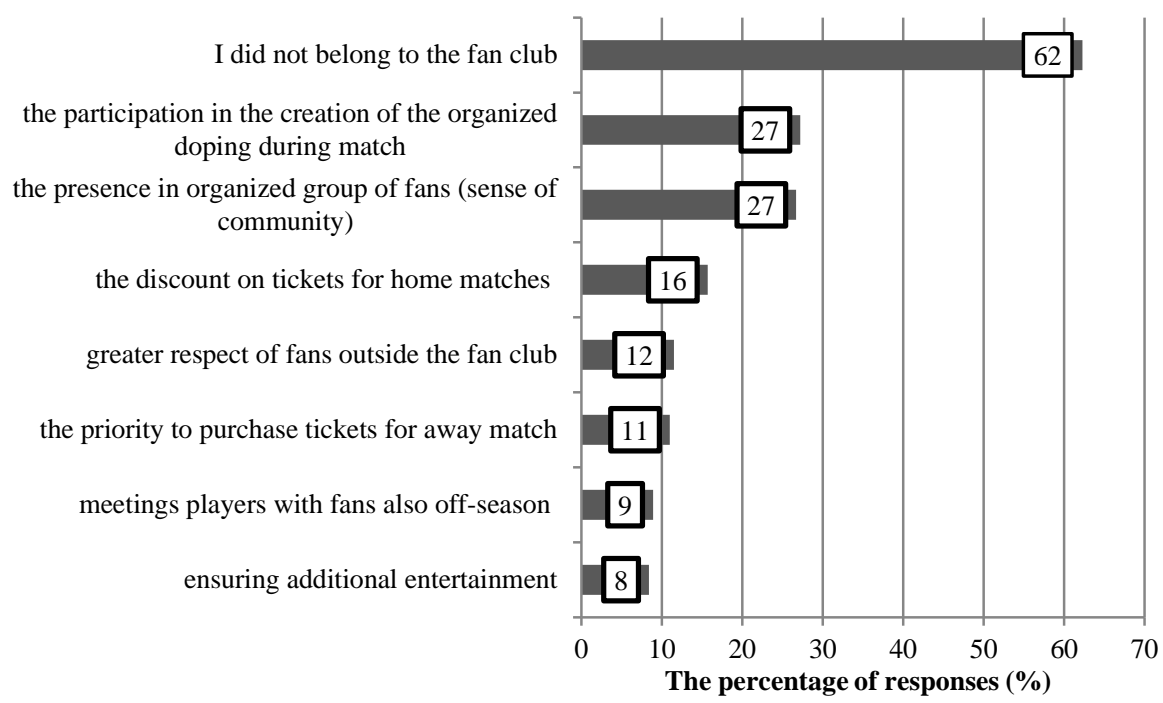

Fig 6. The most important benefits of membership in the Fan Club, according to respondents. In this question was a possibility of multiple choice.

Source: own study based on survey.

The last part of this study was focused to assessing The Fan Club of Twarde Pierniki. The most of the respondents evaluated their level of satisfaction from Fan Club on the good level - scores 4 selected 33\% of respondents. The assessment of 5 and above gave $30 \%$ of examined fans. In turn, the average rating of all responses was 3.79. In the next question asked respondents about the most important benefits of membership in The Fan Club. The vast majority of respondents do not belonged to The Fan Club. This information should interest the club, which has to come up with a new strategy to encourage fans to join the organized group of fans. Among the members of The Fan Club almost every third person $(27 \%)$ indicated the possibility of the participation in the creation of the organized cheering during match and exactly the same number of respondents pointed on sense of community as the main benefits of being in organized group of fans. It maybe surprise that only a few respondents pointed to meetings with players fans also off-season (9\%). It can be supposed that two meetings were not enough. Unfortunately, the players almost a few days after the season came back to their homes.

\section{Conclusion}

This paper maybe a valuable source of knowledge about expectations and needs of sports fans. The fans are the most important customers group for sporting organizations. Hence establishing and maintaining healthy relationship with fans 
should be main point of the strategy of sporting organizations. Therefore, regular survey of satisfaction is one of the elements of relationship marketing, which are necessary to get the high attendance of fans on sports events. What is important, without the fans it is not possible to get a significant sponsor and without sponsorship the club would not exist. Understanding the fans, their expectations and needs is key for sporting organizations.

The results of research which were conducted on basketball fans of favorite team from Torun, showed the high levels of satisfaction with the organizations of sport events (matches and additional attractions), marketing and social activities of club, as well assortment of The Fan Shop (merchandise). Nevertheless, The Fan Club of team Polski Cukier Torun was rated lower than other components of the club activities. This information should interest the club, which has to come up with a new strategy to encourage fans to join the organized group of supporters. Fans, who are not very loyal or committed need to be motivated every once in a while to attend games or buy merchandise.

The information presented in the article maybe also useful for new basketball teams in professional leagues that are trying to find new fans. What is interesting, the sport lovers become basketball fans in youth. The basketball fans value the social actions, e.g. visits of basketball players in schools and kindergartens, the organized trips on away matches, as well as fast and efficient communication of sporting organizations in social media. What is more, basketball fans are beginning to expect the additional attractions and extraordinary services during matches e.g. competitions, exhibitions of historical materials about club or ensuring the special activities for children.

\section{References}

Armstrong, G., Kotler Ph., Marketing. Wprowadzenie, Wolter Kluwer Polska, Warszawa 2012.

Bühler, A., Nufer, G., Relationship Marketing in Sports, Wyd. ButterworthHeinemann, Oxford 2012.

Masterman, G., Strategic Sports Event Management, Routledge, New York 2014.

Christopher, M., Payne, A., Ballatyne, D., Relationship marketing: Creating Stakeholder Value, Routledge Taylor \& Francis Group, London 2013.

Klisiński, J., Teoria i praktyka marketingu $w$ sporcie i biznesie sportowym, WSEiA, Bytom 2008.

Kaczmarczyk, S., Badania marketingowe. Podstawy metodyczne, PWE, Warszawa 2011.

Otto, J., Marketing relacji: koncepcje $i$ stosowanie, C.H. Beck, Warszawa 2004.

Perechuda, K., Zarzadzanie marketingiem w organizacji sportowej, AWF, Wrocław 2006.

Petrykowska, J., Kształtowanie relacji $z$ klientami jako podstawa budowania lojalności, [in:] A. Wiśniewska (Ed.), Ksztattowanie lojalności konsumenckiej, Wyższa Szkoła Promocji, Warszawa 2014. 
Rudawska, E., Interesariusze $w$ marketingu relacji na rynku ustug sportowych, Zeszyty Naukowe Uniwersytetu Szczecińskiego, no. 690, Ekonomiczne problemy usług no. 79, Szczecin 2011.

Shank, M.D., Sports Marketing - A Strategic Perspective, New Jersey: Prentice Hall 2008.

Sznajder A., Marketing sportu, PWE, Warszawa 2012.

Waśkowski, Z., Uwarunkowania $i$ sposoby wdrażania orientacji marketingowej $w$ klubach sportowych, Wyd. Akademii Ekonomicznej, Poznań 2007.

\section{Online resources:}

http://www.twardepierniki.pl (accessed 26 May 2016).

https://www.facebook.com/BasketTorun (accessed 26 May 2016).

http://money.cnn.com/2015/09/10/news/companies/nfl-revenue-profits/ (accessed 26 May 2016). 